\title{
PENGENDALIAN HAMA DAN PENYAKIT TANAMAN JERUK DI DUSUN PAUSAN DESA BUAHAN KAJA KECAMATAN PAYANGAN
}

\author{
I N. Puja ${ }^{1}$, I G.P. Ratna Adi² dan I D. P. Singarsa ${ }^{3}$
}

\begin{abstract}
ABSTRAK
Petani Desa Buahan, Kabupaten Gianyar menghadapi permasalahan adanya serangan hama dan penyakit terhadap tanaman jeruk yang menyebabkan produktivitasnya sangat merosot. Tujuan kegiatan ini adalah mengadakan penyuluhan dan demoplot teknologi pengendalian hama dan penyakit tanaman jeruk. Metode yang digunakan terdiri atas : 1) Penyuluhan dengan materi pengenalan sumber hama dan penyakit tanaman, 2) Demoplot teknik penanggulangan hama dan penyakit tanaman jeruk. 3) Pendampingan secara insedental dan berkala. Hasil kegiatan menunjukkan penanggulangan hama dan penyakit tanaman jeruk dapat berjalan dengan baik berdasarkan rataan partisipasi mitra pada seluruh sub kegiatan sebesar 76,48 \%. Rataan tersebut terdiri dari partisipasi kehadiran anggota subak Abian $75 \%$ dan 30,91 \% dari peserta yang hadir menyampaikan pendapat. Evaluasi adopsi Ipteks, ternyata $100 \%$ peserta telah memahami Ipteks yang disuluhkan dan ikut berpartisipasi pada kegiatan demoplot pengecatan batang pohon dan pembungkusan buah jeruk yang terserang.
\end{abstract}

Kata kunci : Penyuluhan, Demoplot, Pengendalian, Hama, Penyakit, Tanaman Jeruk

\begin{abstract}
Farmers in Buahan Village, Gianyar Regency face problems with pest and disease attacks on citrus crops which caused very low productivity. The purpose of this activity is to explanation and demoplot the technology to control citrus pests and diseases.. The method used consists of: 1) Explanation with material introduction to sources of pests and plant diseases, 2) Demoplot techniques to control pests and diseases of citrus plants. 3) Insedental and periodic assistance. The results of the activity show that the control of citrus pests and diseases can run well based on the average participation of partners in all sub-activities by $76.48 \%$. The average consists of participation in the presence of subak members Abian $75 \%$ and $30.91 \%$ of the participants present to express their opinions. Evaluation of science and technology adoption, it turned out that $100 \%$ of participants had understood the science and technology that was passed on and participated in the demonstration plot of tree trunks and wrapping of attacked citrus fruits.
\end{abstract}

Key words : Explanation, Demoplot, Control, Pests, Desease, Citrus plant.

\footnotetext{
${ }^{1}$ Fakultas Pertanian Universitas Udayana, pujatenganan@yahoo.com

${ }^{2}$ Staff Dosen Fakultas Pertanian Universitas Udayana, ratnadi@unud.ac.id

${ }^{3}$ Staff Dosen Fakultas Pertanian universitas Udayana, dalembali@ yahoo.com
} 


\section{PENDAHULUAN}

Desa Buahan memiliki lahan kebun/tegalan seluas 787 ha, sawah seluas 209 ha, penduduknya sebagian besar masih bermata pencaharian sebagai petani dan desa ini merupakan salah satu jalur lalu lintas pariwisata dari Denpasar - Ubud - Kintamani (Profil Desa, 2010). Adanya potensi desa tersebut, maka perlu mendapatkan prioritas untuk dikembangkan dalam rangka menunjang kebutuhan pariwisata. Petani Desa Buahan mengembangkan pertanian dengan tujuan untuk menunjang kebutuhan pariwisata terhadap buah-buahan khususnya jeruk. Permasalahan petani yang dihadapi di Desa Buahan adalah adanya serangan organisme pengganggu tanaman (OPT) yang mengakibatkan penurunan produktivitas yang cukup tinggi. Menurut Wiratama dkk., (2017) ada 2 jenis spesies lalat buah yang menyerang tanaman jeruk di Kabupaten Gianyar yaiu, B. carambolae dan B. papayae. Gangguan hama yang menjadi ancaman bagi tanaman jeruk petani salah satunya adalah hama lalat buah dan penyakit diplodia. Serangan lalat buah menyerang pada buah yang masih muda dan hampir masak. Kerusakan yang ditimbulkan oleh lalat buah adalah larvanya akan menyebabkan gugurnya buah sebelum mencapai kematangan yang diinginkan. Hal ini sangat merugikan karena dapat menghambat peningkatan produksi dan mutu buah. Buah yang terserang mudah dikenali dengan adannya perubahan warna kulit di sekitar tanda sengatan dan terjadinya pembusukan buah dengan cepat. Pada buah yang terserang biasanya terdapat lubang kecil di bagian tengah kulitnya. Hal tersebut disebabkan oleh larva lalat buah yang hidup di dalam buah yang hampir masak sehingga menyebabkan buah menjadi busuk. Apabila dibelah pada daging buah terdapat belatung-belatung kecil yang biasanya meloncat apabila tersentuh. Penyakit Diplodia atau Blendok merupakan penyakit utama yang menyebabkan kematian pada batang dan cabang tanaman jeruk. Penyebaran penyakit ini hampir di seluruh pertanaman jeruk, terutama yang telah berumur lebih dari 10 tahun. Bagian tanaman yang diserang akan terlihat melingkar pada cabang dan batang utama menyebabkan kematian bagian tanaman di atas titik serangan, bahkan menyebabkan kematian tanaman. Penanggulangan hama dan penyakit telah pernah dilakukan oleh petani dengan menggunakan insektisida, perangkap lalat jantan ( Methyl Eugenol), dan sanitasi kebun tetapi hasilnya belum memuaskan. Menurut Wijaya dkk. (2017) hama dan penyakit tanaman jeruk sangat penting diperhatikan, karena berpengaruh terhadap produktivitas dan bahkan gagal panen, apabila hama dan penyakit jeruk tidak dikelola dengan baik.

Berdasarkan permasalah yang dihadapi petani jeruk ini maka perlu dilakukan demoplot teknologi pengendalian hama dan penyakit tanaman jeruk. Apabila penerapan teknologi ini dapat diterima dan dilaksanakan oleh petani, maka produktivitas tanaman jeruk lebih besar dan penghasilan petani akan bertambah. Permasalahan petani adalah: (1) Bagaimana meningkatkan pengetahuan petani tentang sumber dari hama dan penyakit tanaman jeruk; (2) Bagaimana meningkatkan ketrampilan pengendalian hama dan penyakit tanaman jeruk. Tujuan pengabdian ini adalah mengadakan penyuluhan dan demoplot teknologi pengendalian hama dan penyakit pada kelompok tani Subak Abian Bukit Jati, Desa Pausan, Desa Buahan Kaja, Kabupaten Gianyar, Bali.

\section{METODE PELAKSANAAN}

Khalayak Sasaran, Tempat dan Waktu Kegiatan

Kegiatan penyuluhan dan demoplot ini melibatkan apparat desa dan Kelompok Tani Subak Abian Bukit Jati, Dusun Pausan, Desa Buahan, Kecamatan Payangan, Kabupaten Gianyar. Kegiatan telah dilaksanakan sejak bulan Februari sampai dengan Oktober 2018, terhitung dari koordinasi sampai pendampingan atau akhir kontrak pengabdian. 


\section{Metode kegiatan}

Kegiatan pengabdian masyarakat ini dilaksanakan dengan metode : 1) Penyuluhan penanggulangan serangan hama dan penyakit tanaman jeruk dengan materi: Pengenalan sumber hama dan penyakit. Peran tim pengabdian dominan dalam tahapan ini. 2) Demonstrasi plot teknik penanggulangan hama dan penyakit tanaman jeruk. Peran mitra kelompok tani dominan dalam kegiatan ini. 3) Pendampingan yaitu bimbingan secara insedental dan berkala antara petani sasaran dan pendamping, sehingga Ipteks yang dialihkan dapat dipahami secara mandiri dan 4) Rancangan Evaluasi untuk mengetahui keberhasilan program kemitraan masyarakat ini telah dilakukan 3 (tiga) macam evaluasi yaitu: 1) Evaluasi tingkat partisipasi mitra dilakukan terhadap kehadiran dan menyampaikan pendapat 2) Evaluasi pemahaman atau daya adopsi Ipteks dilakukan dengan jumlah anggota yang berkeinginan menerapkan Ipteks yang disuluhkan dan 3) Evaluasi produk Ipteks yang dihasilkan dilakukan dengan hasil kegiatan demoplot.

\section{HASIL DAN PEMBAHASAN}

Kegiatan penuluhan dan demoplot penanggulangan hama dan penyakit tanaman jeruk dilaksanakan di Banjar Pausan, Desa Buahan Kaja, Kecamatan Payangan, Kabupaten Gianyar dengan jumlah petani yang hadir sebanyak 55 orang. Kegiatan ini dilaksanakan melalui penyuluhan dan demoplot dengan Nara Sumber Bapak Prof. Ir. I Wayan Susila, MS (Gambar 1). Kegiatan ini dilaksanakan berdasarkan kenyataan permasalahan yang dihadapi petani di Desa Buahan yaitu adanya serangan hama dan penyakit pada tanaman jeruk milik petani, sehingga produktivitasnya menjadi merosot.

Pada kegiatan tersebut didahului dengan penyuluhan pengenalan siklus hidup hama lalat buah. Siklus hidup lalat buah mempunyai 4 stadium hidup yaitu telur, larva, pupa dan dewasa. Hama lalat buah betina memasukkan telur kedalam kulit buah jeruk sehingga kulit buah terluka dan buah terlihat cacat secara berkelompok. Lalat betina bertelur \pm 15 butir, telur berwarna putih transparan berbentuk bulat panjang dengan salah satu ujungnya runcing. Telur berkembang menjadi larva lalat buah hidup dan berkembang di dalam daging buah selama 6-9 hari. Larva dapat dilihat apabila buah yang terserang dibelah, akan terlihat belatung-belatung kecil dengan ukuran 4-10 mm. Larva mengorek daging buah sambil mengeluarkan enzim perusak atau pencerna yang berfungsi melunakkan daging buah sehingga mudah dihisap dan dicerna. Enzim tersebut diketahui yang mempercepat pembusukan, selain bakteri pembusuk yang mempercepat aktivitas pembusukan buah. Jika aktivitas pembusukan buah sudah mencapai tahap lanjut, maka buah akan jatuh ke tanah. Bersamaan dengan masaknya buah, larva lalat buah masuk dalam tanah dan berkembang menjadi pupa. Pupa berwarna kecoklatan berbentuk oval dengan panjang $5 \mathrm{~mm}$. Lalat dewasa pada umumnya berwarna merah kecoklatan, dada berwarna gelap dengan 2 garis kuning membujur dan pada bagian perut terdapat garis melintang. Lalat betina ujung perutnya lebih runcing dibandingkan lalat jantan. Siklus hidup dari telur menjadi dewasa berlangsung $\pm 16-24$ hari. Fase kritis tanaman yaitu pada saat tanaman mulai berbuah terutama pada saat buah menjelang masak.

Lalat buah yang mempunyai ukuran tubuh relatif kecil dan siklus hidup yang pendek peka terhadap lingkungan yang kurang baik. Faktor yang mempengaruhi perkembangan lalat buah adalah suhu, kelembaban udara dan cahaya matahari langsung. Suhu optimal untuk perkembangan lalat buah \pm $26^{\circ} \mathrm{C}$, kelembaban udara sekitar $70 \%$ dan Lalat buah betina akan meletakkan telur lebih cepat dalam kondisi yang terang, sebaliknya pupa lalat buah tidak akan menetas apabila terkena sinar matahari langsung.

Lalat buah pada tanaman jeruk paling banyak menyerang pada jenis pemelo (Citrus grandis) dan sedikit yang menyerang jeruk manis (Citrus sinensis) dan keprok (Citrus reticulata) dan Siam (Citrus suhuensis). Pada pamelo, serangan lalat buah kadang-kadang bersamaan dengan serangan 
penggerek buah Citripestis sagitiferella, sehingga agak sulit membedakan serangan tersebut. Lalat buah yang menyerang jeruk pada pamelo dan jeruk manis sudah diidentifikasi sebagai Bactrocera carambolae dan Bactrocera papayae. Sedangkan yang menyerang jeruk siam belum teridentifikasi. Fase kritis tanaman dan saat pemantauan populasi adalah saat buah menjelang masak.

Lalat buah dapat dikendalikan dengan berbagai cara mulai dari tradisional, kimiawi, umpan protein, atraktan, maupun penggunaan teknik jantan mandul (Marpaung dkk., 2014). Lalat buah di alam mempunyai musuh alami berupa parasitoid dari genus biosteres, opius dan beberapa predator seperti semut, sayap jala Chrysopidae va. (ordo Neuroptera), kepik Pentatomide (ordo Hemiptera) dan beberapa kumbang tanah (ordo Coleoptera). Peran musuh alami belum banyak dimanfaatkan mengingat populasinya yang rendah dan parasitoid dan predator ini lebih rentan terhadap insektisida daripada hama yang diserangnya. Petani lebih banyak menggunakan insektisida untuk mengendalikan hama.

Cara mekanis untuk mengendalikan lalat buah dapat dilakukan dengan pemetikan dan pengumpulan buah sisa yang tidak dipanen dan buah sortiran untuk menghindarkan sumber inang yang potensial hama tersebut, dan akan menjadi sumber serangan berikutnya. Pengendalian mekanis dilakukan juga dengan mengumpulkan buah yang busuk atau sudah terserang kemudian dibenamkan kedalam tanah atau dibungkus plastik atau dibakar. Pembungkusan buah mulai umur 1,5 bulan untuk mencegah peletakkan telur (oviposisi), merupakan cara mekanis yang paling baik untuk diterapkan sebagai antisipasi terhadap serangan lalat buah. Pengendalian hama lalat buah secara kultur teknis dapat juga dilakukan dengan pengolahan tanah yaitu tanah bagian bawah disekitar pohon/tajuk tanaman dibalik dengan tanah di permukaan sehingga pupa yang ada di dalam tanah terangkat ke permukaan tanah dan terkena sinar matahari sehingga pupa akan mati.

Pengendalian dengan cara kimia dilakukan dengan menggunakan senyawa perangkap/atraktan yang dikombinasikan dengan insektisida. Senyawa yang umum digunakan adalah Methyl Eugenol. Caranya dengan meneteskan pada segumpal kapas sampai basah namun tidak menetes, ditambah dengan insektisida dan dipasang pada perangkap yang sederhana, modifikasi dari model perangkap Stiener. Alat perangkap terbuat dari botol bekas air minum mineral yang lehernya berbentuk kerucut atau toples plastik. Perangkap dipasang dekat pertanaman atau pada cabang atau ranting tanaman jeruk. Pemasangan dilakukan sejak buah pentil (umur $\pm 1,5$ bulan) sampai panen. Pemberian cairan atraktran diulang setiap 2 minggu sampai 1 bulan. Setiap satu hektar dapat dipasang 15-25 perangkap (Dwiastuti et.al., 2004).

Penyakit utama yang penyerang tanaman jeruk adalah salah satunya penyakit Diplodia atau Blendok. Penanggulangan penyakit Diplodia atau blendok pada tanaman jeruk dapat dilakukan dengan memberikan bubur California yang ditambah bakteri trikorderma. Keunggulan dari bubur kalifornia plus ini adalah terletak pada jamur Trichoderma, jamur ini merupakan jamur tanah yang berpotensi sebagai jamur antagonis yang bermanfaat sebagai agen pengendali hayati yang sangat menguntungkan bagi petani karena kemampuannya untuk mengendalikan penyakit, mampu meningkatkan pertumbuhan serta meningkatkan hasil tanaman. Cara pemberiannya dilakukan dengan mengecat pohon jeruk dari pangkal pohon setinggi $50-75 \mathrm{~cm}$

Para peserta pelatihan menyepakati untuk mempraktekkan langsung dari cara penanggulangan hama dan penyakit tanaman jeruk dalam bentuk demoplot yaitu cara mekanis untuk penanggulangan hama dan bubur California plus trikoderma untuk penanggulangan penyakit.

Demoplot pengendalian hama lalat buah dilakukan dengan cara mekanik yaitu mengumpulkan buah yang telah gugur atau sudah terserang kemudian dibenamkan kedalam tanah atau dibungkus plastik yang berwarna hitam (Gambar 2). Pembungkusan buah dimaksudkan untuk mencegah peletakkan telur (oviposisi) dan cara mekanis ini paling baik untuk diterapkan sebagai antisipasi terhadap serangan lalat buah. Demoplot untuk penanggulangan penyakit Diplodia atau Blendok pada tanaman jeruk dilakukan pengecatan 500 pohon tanaman jeruk milik petani peserta dengan 
bubur California yang ditambah jamur trikorderma (Gambar 3). Penyakit Diplodia atau Blendok akan terjadi apabila petani kurang intensif dalam pemeliharaan tanaman, kondisi kekeringan, adanya pelukaan dan perbedaan suhu siang dan malam yang tinggi.

Evaluasi kegiatan pengabdian ini dilakukan pada setiap kegiatan melalui : 1) Evaluasi tingkat partisipasi mitra, 2) Evaluasi pemahaman atau daya adopsi Ipteks dan 3) Evaluasi produk Ipteks yang dihasilkan. Evaluasi tingkat partisipasi mitra dilakukan terhadap kehadiran dan menyampaikan pendapat. Pemahaman/adopsi Ipteks dilakukan dengan jumlah anggota yang berkeinginan menerapkan Ipteks yang disuluhkan dan Evaluasi produk Ipteks dilakukan dengan hasil kegiatan demoplot. Secara rinci partisipasi mitra disajikan pada Tabel 1.

Tabel 1. Partisifasi Mitra dalam kegiatan

\begin{tabular}{|l|l|c|c|}
\hline \multirow{2}{*}{ No } & \multicolumn{1}{|c|}{ Kegiatan } & Jumlah & Mitra \\
\cline { 2 - 4 } & & & \\
\hline 1 & Tingkat Partisifasi Mitra & 55 & 75 \\
\hline & -Kehadiran & 17 & 30,91 \\
\hline & -Menyampaikan pendapat & & 100 \\
\hline 2 & Pemahaman/Adopsi Ipteks & 55 & 100 \\
\hline & -Ingin melaksanakan & & 76,48 \\
\hline 3 & Produk Ipteks & 55 & \\
\hline & -Partisipasi kegiatan Demoplot & & \\
\hline \multicolumn{2}{|c}{ Rata-rata } \\
\hline
\end{tabular}

Hasil kegiatan menunjukkan perbaikan budidaya tanaman jeruk dapat berjalan dengan baik berdasarkan rataan partisipasi mitra pada seluruh sub kegiatan adalah sebesar 76,48 \%. Rataan tersebut terdiri dari partisipasi kehadiran anggota subak $75 \%$ dari jumlah anggota 73 orang, dan $30,91 \%$ dari anggota yang hadir menyampaikan pendapat. Evaluasi pemahaman/adopsi Ipteks dari peserta ternyata $100 \%$ telah memahami sehingga mereka akan melakukan cara-cara penanggulangan hama dan penyakit pada lahan tanaman jeruknya. Evaluasi produk Ipteks dilakukan melalui partisipasi di demoplot (pengecatan dan pembungkusan buah jeruk yang terserang) sebesar100\%.

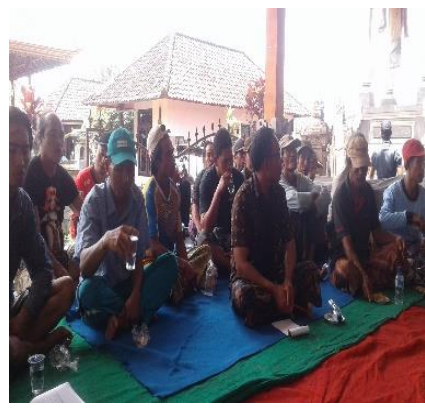

Gambar 1. penyuluhan

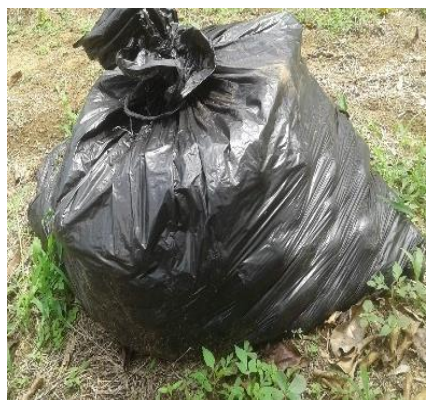

Gambar 2. Membungkus buah terserang

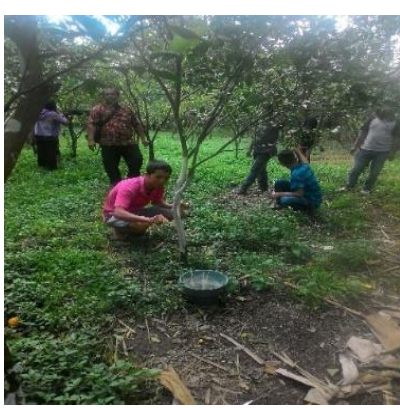

Gambar 3. Pengecatan batang pohon 


\section{KESIMPULAN DAN SARAN}

Berdasarkan hasil kegiatan yang telah dilaksanakan maka dapat disimpulkan beberapa hal yaitu sebagai berikut :

1. Pengendalian hama dan penyakit belum dilakukan secara serentak, sehingga masih terdapat sumber hama dan penyakit pada buah berserakkan.

2. Inovasi Teknik penanggulangan hama dan penyakit tanaman jeruk dapat berjalan dengan baik berdasarkan rataan partisipasi mitra pada seluruh sub kegiatan adalah rata-rata sebesar $75 \%$. Nilai rata-rata tersebut terdiri atas partisipasi kehadiran $72 \%$, menyampaikan pendapat $39 \%$, pemahaman/adopsi Ipteks $74 \%$ dan partisifasi kegiatan di demoplot sebesar $83 \%$.

Berdasarkan hasil kegiatan ini maka dapat disarankan hal-hal sebagai berikut :

1. Penanggulangan hama dan penyakit tanaman jeruk perlu dilakukan secara serentak pada seluruh areal, sehingga sumber hama dan penyakit dapat ditangani secara dini.

2. Program Kemitraan Wilayah (PKW) perlu dikembangkan ke daerah lain karena sangat sesuai dengan kebutuhan masyarakat pedesaan.

\section{UCAPAN TERIMA KASIH}

Tim pengabdi mengucapkann terimakasih kepada Direktorat Riset dan Pengabdian Kepada Masyarakat Direktorat Jenderal Penguatan Riset dan Pengembangan Kementerian Riset, Teknologi dan Pendidikan Tinggi atas dana yang diberikan sehingga kegiatan pengabdian kepada masyarakat ini dapat berjalan dengan baik . Tim juga berterima kasih kepada Pemerintah Kabupaten Gianyar, kepada Kepala Desa Buahan Kaja dan semua pihak yang tidak dapat sebutkan namanya satu persatu oleh tim atas bantuan dan dukungannya terhadap kegiatan ini dapat diselesaikan dengan baik.

\section{DAFTAR PUSTAKA}

Marpaung A.Y.A., Yuswani Pangestiningsih, Mukhtar Iskandar Pinem. 2014. Survei Pengendalian Hama Terpadu Hama Lalat Buah Bactrocera spp. Pada Tanaman Jeruk di Tiga Kecamatan Kabupaten Karo. Jurnal Online Agroekoteknologi . Vol.2 (4) : 1316- 1323

Badan Perencanaan Pembanguanan Kabupaten Gianyar. 2011. Rencana Pembangunan Jangka Menengah Kabupaten Gianyar.

Pemerintahan Desa Puhu. 2010. Profil Pembangunan Desa Puhu tahun 2010.

Wijaya N., W. Adiartayasa, I G.P. Wirawan, M. Sritamin, M. Puspawati dan I M. Sudarma. 2017. Hama Dan Penyakit Pada Tanaman Jeruk Serta Pengendaliannya. Buletin Udayana Mengabdi, Volume $16(1): 51-57$

Wiratama M.D., I W. SUSILA dan I W. SUPARTHA. 2017. Jenis Lalat Buah Bactrocera spp. (Diptera : Tephritidae) yang Menyerang Pertanaman Jeruk di Kabupaten Gianyar dan Bangli. E-Jurnal Agroekoteknologi Tropika . Vol. 6 (4) : 405 - 413 